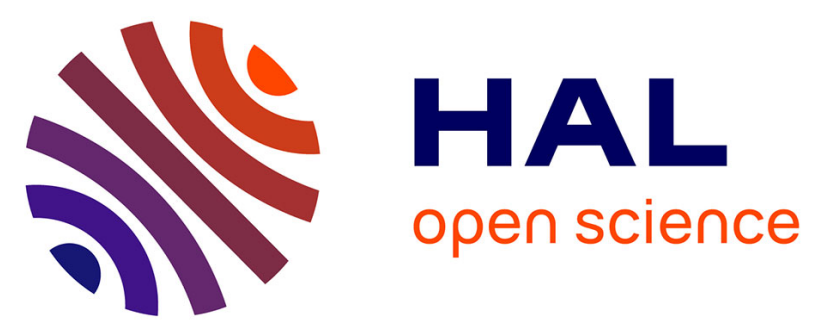

\title{
Secondary metabolites of Bagassa guianensis Aubl. wood: A study of the chemotaxonomy of the Moraceae family
}

Mariana Royer, Gaëtan Herbette, Véronique Eparvier, Jacques Beauchêne, Bernard Thibaut, Didier Stien

\section{To cite this version:}

Mariana Royer, Gaëtan Herbette, Véronique Eparvier, Jacques Beauchêne, Bernard Thibaut, et al.. Secondary metabolites of Bagassa guianensis Aubl. wood: A study of the chemotaxonomy of the Moraceae family. Phytochemistry, 2010, 71, pp.1708-1713. 10.1016/j.phytochem.2010.06.020 . hal00857200

\section{HAL Id: hal-00857200 https://hal.science/hal-00857200}

Submitted on 3 Sep 2013

HAL is a multi-disciplinary open access archive for the deposit and dissemination of scientific research documents, whether they are published or not. The documents may come from teaching and research institutions in France or abroad, or from public or private research centers.
L'archive ouverte pluridisciplinaire HAL, est destinée au dépôt et à la diffusion de documents scientifiques de niveau recherche, publiés ou non, émanant des établissements d'enseignement et de recherche français ou étrangers, des laboratoires publics ou privés. 
2 Secondary metabolites of Bagassa guianensis Aubl. wood, a study of the chemotaxonomy 3 of the Moraceae family.

4

5 Mariana Royer ${ }^{1}$; Gaëtan Herbette ${ }^{2}$; Véronique Eparvier ${ }^{1}$; Jacques Beauchêne ${ }^{3}$; Bernard 6 Thibaut $^{1}$; Didier Stien ${ }^{1, *}$

7

8 Affiliations

9

${ }^{1}$ CNRS, UMR Ecofog, Université des Antilles et de la Guyane, Cayenne, France

${ }^{2}$ Spectropole, FR 1739 - Université d'Aix-Marseille, Faculté de Saint-Jérôme, service 511,

Avenue Escadrille Normandie Niémen, 13397 Marseille cedex 20, France

$13{ }^{3}$ Cirad, UMR Ecofog, BP 709, F-97387 Kourou, France

Corresponding authors

16

Dr. Didier Stien, CNRS, UMR Ecofog, Institut d'Enseignement Supérieur de la Guyane, BP 


\section{Abstract}

25

In effort to explain wood durability of Moraceae plants family, a phytochemical study was undertaken on Bagassa guianensis. The phytochemical investigation of the ethyl acetate extract obtained from the heartwood led to the isolation of 18 secondary metabolites, including 6 moracins [the new 6-O-methyl-moracin $\mathrm{M}(3), 6-O$-methyl-moracin $\mathrm{N}(4)$ and moracin $\mathrm{Z}(\mathbf{5})$; the known moracin $\mathrm{M}(\mathbf{1})$, moracin $\mathrm{N}(\mathbf{2})$ and moracin $\mathrm{P}(\mathbf{6})], 8$ phenolic derivatives [the new (-)-epialboctalol (12), arachidin 4 (10) and the known alboctalol (11), trans-resveratrol (7), arachidin $2(\mathbf{9})$, trans-oxyresveratrol (8) and artogomezianol (13)], the 3 known flavonoids steppogenin (14), katuranin (15), dihydromorin (16), the $\beta$-sitosterol (17) and the resorcinol (18). Comparison with literature data indicates that stilbenoids are presumably responsible for the natural durability of the wood. In addition, chemical composition points out that B. guianensis is closely related to Morus sp. in the phylogeny and should be placed within the Moreae s. s. tribe in the Moraceae family.

Keywords: Bagassa guianensis, Moraceae, secondary metabolites, stilbenes, moracins, flavonoids, natural durability 


\section{Introduction}

Wood as a material is used extensively in construction and other applications where it can be degraded by many different organisms, mainly fungi and insects. However, some trees have specialized considerably long-lasting heartwoods. It has been demonstrated in the past that wood natural durability can be ascribed to the presence of extractives (Smith et al., 1989; Wang et al., 2005; Hsu et al., 2007), although structural components of the cell wall may also contribute to its resistance to biodegradation (Silva et al., 2007). Heartwood natural durability can also result from synergetic or additive effects of compounds with various modes of action (toxic, hydrophobic, free radical scavengers and so on) (Suttie and Orsler, 1996; Okitani et al., 1999; Schultz and Nicholas, 2000; Schultz et al. 2007; Binbuga et al., 2008). Future processes to preserve wood constructions may involve returning to mankind's historical use of naturally durable heartwood as well as discovering eco-friendly wood protection agents inspired from long-lasting woods (Schultz et al., 2007).

Bagassa guianensis Aubl. (Moraceae) commercially known as tatajuba is a large rather infrequent unbuttressed canopy tree naturally occurring in French Guiana. Bagassa guianensis is a member of Moraceae family, which is divided in 5 unequal tribes when comparing the number of species in these tribes (Mabberley, 2002). Bagassa guianensis (the only member of its genus) was originally classified in the Artocarpeae tribe, but Weiblen genoma-based classifications have suggested recently that this species would better be included in Moreae tribe (Datweyler and Weiblen, 2004; Zerega et al, 2005).

Species in the Moraceae family have important economic and medicinal value. They are widely acknowledged as a rich source of bioactive secondary metabolites such as flavonoids, 
stilbenes, triterpenoids and xanthones (Lee et al., 2009; Ngadjui et al., 2005; Han et al., 2006; Jayasinghe et al., 2008). Also, some of them like Maclura pomifera and B. guianensis are capable of specializing very long-lasting woods (Scheffer and Morrell, 1998; Schultz et al., 1995), although in the latter case, the substances responsible for this high durability were unknown. We therefore embarked upon identifying secondary metabolites of tatajuba wood that may responsible for its natural durability. In addition, our secondary goal here was to confirm (or refute) botanical classification of the Bagassa genus by chemotaxonomy.

\section{Results and Discussion}

The dried heartwood of Bagassa guianensis was extracted with ethyl acetate. This extract was fractionated by silicagel column chromatography to give 9 fractions. Subsequent preparative HPLC purifications of these fractions allowed us to isolate compounds 1-18 (figure 1).

Figure 1 Compounds 1-18 isolated from Bagassa guianensis (Moraceae). (a) New compounds; (b) New names.

Compounds 1 to 6 shared several common spectral characteristics. The ${ }^{1} \mathrm{H}$ and ${ }^{13} \mathrm{C}$ NMR spectral data (Table 1) indicate the presence of two independent aromatic systems with a 3,5dihydroxyphenyl and a substituted benzofuran. For example, 3 exhibited the 3,5dihydroxyphenyl with characteristic ${ }^{1} \mathrm{H}$ spectrum composed of one doublet at $\delta 6.78$ for $\mathrm{H}$ 2'/H-6' and a triplet at $\delta 6.25$ for H-4'. These protons are coupled to each other with a ${ }^{4} J$ coupling of $2.1 \mathrm{~Hz}$. In addition, ${ }^{13} \mathrm{C}$ spectrum indicates the presence of two equivalent aryl hydroxyl groups at $\delta$ 159.7. The 3,5-dihydroxyphenyl moiety was linked to C-2 by the observation of a long range ${ }^{1} \mathrm{H}_{-}{ }^{13} \mathrm{C}$ correlation between $\mathrm{H}-2$ '/H-6' and $\mathrm{C}-2$ at $\delta$ 156.5. The second aromatic system appeared characteristic of a 6-monosubstituted benzofuran with 
signals of protons $\mathrm{H}-4, \mathrm{H}-5$ and $\mathrm{H}-7$ being a broad doublet at $\delta 7.43(\mathrm{~J}=8.5 \mathrm{~Hz})$, a doublet of doublet at $\delta 6.85(J=8.5$ and $2.0 \mathrm{~Hz})$ and a doublet at $\delta 7.09(J=2.0 \mathrm{~Hz})$, respectively. On the furan ring H-3 gives a doublet at $\delta 6.95(J=0.6 \mathrm{~Hz})$ due to a long range ${ }^{5} J$ coupling with H-7 (confirmed by the presence of crosspeak between H-3 and H-7 on COSY NMR spectrum). When compared to moracin M (1), it became obvious from signal at $\delta 3.85(3 \mathrm{H}, \mathrm{s})$ and the presence of crosspeak at $\delta 56.2$ in the ${ }^{1} \mathrm{H}^{-1}{ }^{13} \mathrm{C}$ HSQC spectra that compound $\mathbf{3}$ was a moracin $\mathrm{M}$ methyl ether. The ${ }^{1} \mathrm{H}_{-}{ }^{13} \mathrm{C}$ long-range $\mathrm{HMBC}$ spectra gave a crosspeak with $\mathrm{C}-6$ at $\delta 159.6$ unambiguously placing the methoxy group on C-6. HREIMS of $\mathbf{3}$ allowed us to ascertain molecular formula $\mathrm{C}_{15} \mathrm{H}_{12} \mathrm{O}_{4}$ further confirming that we had isolated the new $6-O$ methyl-moracin M (3).

\section{Table $1{ }^{1} \mathrm{H}$ and ${ }^{13} \mathrm{C}$ NMR spectroscopic data for moracins 3-5 in $\mathrm{CD}_{3} \mathrm{OD}$}

Compound 4 was isolated as yellowish amorphous powder. The HREIMS indicated a molecular formula $\mathrm{C}_{20} \mathrm{H}_{20} \mathrm{O}_{4}$ deduced from the ion peack at $\mathrm{m} / z 325.1437[\mathrm{M}+\mathrm{H}]^{+}$(calcd 325.1434). The ${ }^{1} \mathrm{H}$ and ${ }^{13} \mathrm{C}$ NMR spectral data of 4 were closely related to those of moracin $\mathrm{N}$ (2) (Lee et al., 2001) except for the replacement of hydroxyl group by a methoxy group as described for the above compound 3. Indeed, the ${ }^{1} \mathrm{H}$ NMR data of 4 (Table 1) demonstrated the presence a methoxy group on C-6 in the benzofuran ring, with a signal at $\delta 3.88(3 \mathrm{H}, \mathrm{s})$, a crosspeak at $\delta 56.2$ in the ${ }^{1} \mathrm{H}_{-}{ }^{13} \mathrm{C}$ HSQC experiment and a crosspeak with C-6 at $\delta 157.4$ in the ${ }^{1} \mathrm{H}_{-}{ }^{13} \mathrm{C}$ long-range $\mathrm{HMBC}$ spectra. This novel molecule was named 6-O-methyl-moracin N. 
Compound 5 was isolated as an amorphous brown powder. The molecular formula $\mathrm{C}_{20} \mathrm{H}_{22} \mathrm{O}_{5}$ was deduced from the HREIMS at $m / z 343.1542[\mathrm{M}+\mathrm{H}]^{+}($calcd 343.1540$)$. The ${ }^{1} \mathrm{H}-$ and ${ }^{13} \mathrm{C}-$ NMR spectral data of 5 were closely related to those of 6-O-methyl-moracin N (4) (Table 1). The main difference was observed in the prenyl moiety at C-5. The double bond is absent in $\mathbf{5}$ and it was unambiguously established that side chain at C-5 is hydrated and is therefore a 3hydroxy-3-methylbutyl group, with the upfield shifts of methylene group H-1', from $\delta 3.34$ to $\delta 2.73$ and the apparition of a methylene $\mathrm{H}-2$ '” at $\delta 1.74$ in place of the vinyl proton at $\delta 5.52$; in addition, the two methyl groups H-4"' and H-5" became equivalent at $\delta 1.27$ (Table 1). The ${ }^{1} \mathrm{H}^{-13} \mathrm{C}$ long-range HMBC spectra exhibited a crosspeak between the methylene group H1', and H-2"' with C-5 at $\delta 128.6$ proving the linkage C-1"'/C-5 between the 3-hydroxy-3methylbutyl moiety and the benzofuran ring. This molecule is a hydrate of 6-O-methylmoracin $\mathrm{N}$ and was named moracin $\mathrm{Z}$.

Spectral data along with HREIMS of 1, 2 and $\mathbf{6}$ allowed us to determine and ascertain by comparison with literature data that we had also isolated moracin M (1) (Basnet et al. 1993, Zhou et al., 1999), moracin N (2) (Lee et al. 2001) and moracin P (6) (Dat et al., 2009).

Stilbenoids trans-resveratrol (7) (Lee et al. 2001; Su et al., 2002), trans-oxyresveratrol (8) (Likhitwitayawuid and Sritularak, 2001; Lee et al., 2001; Su et al., 2002; Li et al., 2007), arachidin 2 (9) (Orsini et al., 2004) and artogomezianol (13) (Likhitwitayawuid and Sritularak, 2001) were identified by comparison of the respective spectral and chemical data with those described in the literature (Figure 1).

Compound $\mathbf{1 0}$ was a colorless syrup with molecular formula $\mathrm{C}_{19} \mathrm{H}_{22} \mathrm{O}_{4}$ as deduced from the HREIMS at $m / z 315.1592[\mathrm{M}+\mathrm{H}]^{+}($calcd 395.1591$)$. The ${ }^{1} \mathrm{H}$ spectral data of $\mathbf{1 0}$ were closely 
related to those of arachidin $2(\mathbf{9})$ (Table 2) and suggested a stilbenoid compound with a paradisubstituted aromatic ring $\mathrm{A}$, a trans double bond between the aromatic rings, and a 1',3',4',5'-tetrasubstituted aromatic ring B. Ring A is symmetrical, with 2 doublets at $\delta 7.32$ $(J=8.7 \mathrm{~Hz}, \mathrm{H}-2 / \mathrm{H}-6)$ and $\delta 6.75(J=8.7 \mathrm{~Hz}, \mathrm{H}-3 / \mathrm{H}-5)$. The trans configuration of the double bond can be ascertained by the very large coupling constant between the two protons at $\delta 6.90$ $(J=16.5 \mathrm{~Hz}, \mathrm{H}-\alpha)$ and $\delta 6.74(J=16.5 \mathrm{~Hz}, \mathrm{H}-\beta)$, and the B ring is symmetrical as well and was characterized by a singlet at $\delta 6.46\left(\mathrm{H}-2^{\prime} / \mathrm{H}-6^{\prime}\right)$. In the same way as we identified a hydrated side chain in the moracins series, the main difference here between $\mathbf{9}$ and $\mathbf{1 0}$ is in the side chain in position 4', the double bond of which is also hydrated. This has been established by the observation of methylene group $\mathrm{H}-1$ ' at $\delta 2.66$ instead of $\delta 3.28$ and the apparition of a second methylene $\mathrm{H}-2$ "' at $\delta$ 1.68. In addition, the two methyl groups H-4" and H-5" became equivalent at $\delta 1.25$. The chromatography collected quantities was too low to observe heteronuclear ${ }^{1} \mathrm{H}_{-}{ }^{13} \mathrm{C}$ HSQC / $\mathrm{HMBC}$ correlations and direct ${ }^{13} \mathrm{C}$ chemicals shifts by ${ }^{13}$ C/DEPTQ sequence. However, the above-described data in comparison with those of arachidin 2 are sufficient to ascertain identification of compound $\mathbf{1 0}$ as trans-4'-(3-hydroxy-3methylbutyl)-oxyresveratrol. We named this new compound arachidin 4 .

\section{Table $2{ }^{1} \mathrm{H}$ and ${ }^{13} \mathrm{C}$ NMR spectroscopic data for stilbenes 9 and $\mathbf{1 0}$ in $\mathrm{CD}_{3} \mathrm{OD}$}

Compounds 11 and 12 both isolated as brownish syrups presented the ion peak at $\mathrm{m} / \mathrm{z}$ 489.1540 $[\mathrm{M}+\mathrm{H}]^{+}$in HREIMS indicating that they are isomers with molecular formulas $\mathrm{C}_{28} \mathrm{H}_{24} \mathrm{O}_{8}$ (calcd 489.1544). The ${ }^{1} \mathrm{H}-\mathrm{NMR}$ allowed us to identify a 3,5-dihydroxyphenyl group and two distinct 2,4-dihydroxyphenyl groups in both compounds. By comparison of the respective spectral and chemical data with those described in the literature, compound $\mathbf{1 1}$ was 
identified as alboctalol (Bates et al., 1997). Compound 12 has an $[\alpha]_{\mathrm{D}}{ }^{20}$ value of $-7.4^{\circ}$ (c $\left.0.004, \mathrm{CH}_{3} \mathrm{OH}\right)$. It was clear that $\mathbf{1 2}$ was a diastereoisomer of $\mathbf{1 1}$ with equivalent $\mathrm{H}-18 / \mathrm{H}-22$ protons at $\delta 6.01$ (Table 3). In 11, H-18/H-22 pair gives a doublet at a strong upfield shift of $\delta$ 5.77 typical of the $\pi$-stacking effect of the neighboring 2,4-dihydroxyphenyl groups. In addition, on this aliphatic ring, the main differences with $\mathbf{1 1}$ are on methylene H-5 and methines H-6, H-7 and H-8. H-5 ax at $\delta 3.19$ exhibited a broad triplet with large couplings $(J=$ 13.7 $\mathrm{Hz}$ ) with the gem $\mathrm{H}-5_{\text {eq }}$ and the vicinal $\mathrm{H}-6$ suggesting that the 6-aryl group should be equatorial and proton H-6 axial. This observation was corroborated by the multiplicity of H$5_{\text {eq }}$ signal at $\delta 2.72$. This signal is a doublet of doublet with a large coupling constant $J=15.6$ $\mathrm{Hz}$ with $\mathrm{H}-5_{\mathrm{ax}}$ and a small coupling constant $J=3.0 \mathrm{~Hz}$ with $\mathrm{H}-6_{\mathrm{ax}}$. Signal of $\mathrm{H}-6_{\mathrm{ax}}$ at $\delta 3.51$ is a broad triplet of doublet with two larges coupling constants $J=11.6 \mathrm{~Hz}$ with $\mathrm{H}-5_{\mathrm{ax}}$ and $\mathrm{H}$ 7 and a small coupling constant $J=2.1 \mathrm{~Hz}$ with $\mathrm{H}-5_{\text {eq. }}$ This pattern indicates that the 7 -aryl group is equatorial and $\mathrm{H}-7$ axial. $\mathrm{H}-7_{\mathrm{ax}}$ at $\delta 3.41$ exhibited one doublet of doublet with one large coupling constant $(J=11.3 \mathrm{~Hz})$ with $\mathrm{H}-6_{\mathrm{ax}}$ and a second rather large coupling constant $(J=8.2 \mathrm{~Hz})$ with $\mathrm{H}-8$ indicating that the 8 -aryl group might be equatorial and proton $\mathrm{H}-8$ axial. These assumptions were confirmed by NOESY experiment with cross peaks observed between $\mathrm{H}-5_{\mathrm{eq}}$ and $\mathrm{H}-\mathrm{6}_{\mathrm{ax}}, \mathrm{H}-\mathrm{6}_{\mathrm{ax}}$ and $\mathrm{H}-\mathrm{8}_{\mathrm{ax}}, \mathrm{H}-\mathrm{6}_{\mathrm{ax}}$ and $\mathrm{H}-18, \mathrm{H}-8_{\mathrm{ax}}$ and $\mathrm{H}-22$ and between $\mathrm{H}-5_{\mathrm{ax}}$ and $\mathrm{H}-16, \mathrm{H}-7_{\mathrm{ax}}$ and $\mathrm{H}-16, \mathrm{H}-7_{\mathrm{ax}}$ and $\mathrm{H}-28$ (Figure 2). All data permitted to confirm that we had isolated a new epimer of alboctalol (11) therefore named (-)-epialboctalol (12).

Table $3{ }^{1} \mathrm{H}$ and ${ }^{13} \mathrm{C}$ NMR spectroscopic data for distilbenes $\mathbf{1 1}$ and $\mathbf{1 2}$ in $\mathrm{CD}_{3} \mathrm{OD}$

Figure 2 Pertinent NOE interactions observed for (-)-epialboctalol (12) from NOESY experiment 
190 In addition to these moracins and stilbenoids, we isolated flavanones steppogenin (14) (Lee et al., 2001), katuranin (15) (Lee et al., 2001) and dihydromorin (16) (Su et al., 2002), together with $\beta$-sitosterol (17) (Basnet et al., 2003, Aldrich Library of 13C and 1H FT NMR spectra, 1992) and resorcinol (18) (Aldrich Library of 13C and 1H FT NMR spectra, 1992). These known compounds were identified by comparison of the respective spectral and chemical data 195 with those described in the literature.

Essentially three classes of compounds were isolated in this study: moracins, stilbenes and flavanones. Only resorcinol 18 and $\beta$-sitosterol 17 do not belong to these classes. These two compounds are widely distributed in nature and cannot be viewed as chemotaxonomic markers.

Moracin N, M and P have been isolated before from Morus alba. In general, it was found from the literature that Morus genus is purveyor of moracins (Tagasuki et al., 1979; Hirakura et al., 1986; Basnet et al., 1993; Nguyen et al., 2009). The only one exception is the isolation of moracin M from Artocarpus dadah (Su et al., 2002).

Among stilbenes, trans-oxyresveratrol was isolated from various plants including Morus sp. and Artocarpus sp. (Hirakura et al, 1986; Su et al, 2002; Shimizu et al., 1998; Song et al, 2009). Trans-resveratrol was isolated from many sources including the Moraceae Cudrania javanensis classified today as Maclura cochinchinensis (Murti et al., 1972, Chapman \& Hall, 2006). The distylbene artogomezianol 13 is a constituent of Artocarpus gomezianus roots and albolactol 11 was isolated from heartwood of Morus alba (Likhitwitayawuid and Sritularak 2001, Ferlinahayati et al., 2008). 
215 Regarding flavonoids, it has been described that many Moraceae can produce steppogenin

(El-Sohly et al, 1999; Su et al, 2002; Sheu et al., 2005). Katuranin was also isolated from

217

various biological sources in Morus and Maclura genera (El-sohly et al., 1999, Lee at al., 2009) and dihydromorin was isolated from Morus, Artocarpus, and Maclura genera (Shimizy et al., 1998, El-Sohly et al, 1999, Su et al., 2002).

It has been hypothesized before that stilbenes are the major types of compounds isolated from Moraceae and may be useful chemotaxonomic markers (Rowe and Conner, 1979). Also, Schultz has shown that stilbenoids play an important role in the high natural durability of Maclura pomifera wood (Schultz et al., 1990). Stilbenes are known as fungicide, termicides and bactericide (Hart and Shrimpton, 1979; Likhitwitayawui and Sritularak, 2001; Javasinghe et al., 2004), and may also exhibit antioxidant properties (Dani et al., 2008; Iacopini et al., 2008; Luo et al., 2005). If it is reasonable to believe that stilbenes are responsible for Bagassa guianensis heartwood natural durability based on literature precedents, stilbenes can be considered as a secondary chemotaxonomic marker here indicating that Bagassa is related to Morus, Artocarpus, and Maclura genera. In Weiblen classification, Artocarpus belongs to the Artocarpeae tribe and Maclura belongs to the Moreae sensu largo tribe, and both Moreae and Artocarpeae tribes are rather closely related genetically.

The peculiarity of B. guianensis in comparison with other Moraceae is the very high proportion of moracins. In this matter, it can be hypothesized that Bagassa genus is closely related to Morus and that moracins are specific to these two genera. These findings are in agreement with Weiblen genetic-based classification where both Bagassa and Morus belong to the Moreae sensu stricto tribe. It should be mentioned that the Sorocea genus, which also belongs to the Moreae s. s. tribe, has been investigated before in the literature and apparently 
does not contain moracins (see for example Ferrari et al., 2003; Ross et al., 2008). This observation speaks in favor of a very close relationship between Bagassa and Morus.

\section{Concluding remarks}

Studies of defensive wood chemicals in Bagassa guianensis allowed us to identify large amount of diversely functionalized stilbenes presumably responsible for wood natural durability. In addition, it was found based on the presence of moracins that Bagassa is very closely related to Morus genus, therefore corroborating Weiblen phylogenetic classification where B. guianensis belongs to the Moreae s. s. tribe rather than to the Artocarpeae tribe.

\section{Experimental}

\subsection{General experimental procedure}

The ${ }^{1} \mathrm{H}$ and ${ }^{13} \mathrm{C}-\mathrm{NMR}$ spectra were recorded on a Bruker Avance DRX500 spectrometer $\left({ }^{1} \mathrm{H}\right.$ 500.13 MHz) equipped with a $5 \mathrm{~mm}$ triple resonance inverse Cryoprobe TXI $\left({ }^{1} \mathrm{H}-{ }^{13} \mathrm{C}-{ }^{15} \mathrm{~N}\right)$, with z gradient. Spectra were recorded with $1.7 \mathrm{~mm}$ NMR capillary tube in $40 \mu \mathrm{L}$ of $99.99 \%$ $\mathrm{CD}_{3} \mathrm{OD}$ solvent $\left(\delta_{1 \mathrm{H}} 3.31 \mathrm{ppm}-\delta_{13 \mathrm{C}} 49.00 \mathrm{ppm}\right)$ at $300 \mathrm{~K}$. The ${ }^{1} \mathrm{H}(500 \mathrm{MHz})$ and ${ }^{13} \mathrm{C} \mathrm{NMR}$ $(125 \mathrm{MHz})$ data are reported in ppm downfield from tetramethylsilane. Coupling constants are in $\mathrm{Hz}$ and s stands for singlet, $\mathrm{d}$ for doublet, $\mathrm{t}$ for triplet, $\mathrm{q}$ for quartet, $\mathrm{m}$ for multiplet and $\mathrm{br}$ for broad. Hydrogen connectivity $\left(\mathrm{C}, \mathrm{CH}, \mathrm{CH}_{2}, \mathrm{CH}_{3}\right)$ information was obtained from edited HSQC and/or DEPTQ-135 experiments. Proton and carbon peak assignments were based on 2D NMR analyses (COSY, NOESY, HSQC and HMBC). HREI-MS were performed using a QStar Elite mass spectrometer (Applied Biosystems SCIEX, Concord, ON, Canada) equipped with an ESI source operated in the positive ion mode. The capillary voltage was set at 5,500 $\mathrm{V}$, the cone voltage at $20 \mathrm{~V}$ and air was used as the nebulizing gas (20 psi). In this hybrid instrument, ions were measured using an orthogonal acceleration time-of-flight (oa-TOF) 
mass analyzer. Analyst software version 2.1 was used for instrument control, data acquisition and data processing. The accurate mass measurements were performed in triplicate with two internal calibrations. Direct sample introduction was performed at a $5 \mu \mathrm{L} / \mathrm{min}$ flow rate using a syringe pump. The UV spectra were recorded on a Perkin-Elmer Lambda 5 spectrophotometer . Optical rotations were measured with a Perkin-Elmer 241 polarimeter equipped with a sodium lamp (589 nm) and a $1 \mathrm{dm}$ cell. The HPLC separations were performed on a Supelco Discovery ${ }^{\circledR}$ HS PEG column $(250 \times 21.1 \mathrm{~mm}, 5 \mu \mathrm{m})$ using a Waters system equipped with a W600 pump and a W2996 photodiode array absorbance detector. The samples were injected manually through a Rheodyne injector and the flow rate was 15 mL.min ${ }^{-1}$. Silica gel $60(35-70 \mu \mathrm{m})$ and analytical TLC plates (Si gel $\left.60 \mathrm{~F} 254\right)$ were purchased from SDS (France). All other chemicals and solvents were analytical grade and purchased from SDS (France).

\subsection{Plant Material}

Bagassa guianensis was collected in Régina, French Guiana. A voucher specimen is kept at the herbarium of Cayenne (CAY-RA13), French Guiana.

\subsection{Extraction and isolation}

The dried powdered heartwood of Bagassa guianensis (140 g) was extracted with ethyl acetate $(3 \times 500 \mathrm{~mL})$ at room temperature to give a crude extract which was fractionated first on a silica gel column chromatography with polarity gradient of hexane/ethyl acetate mixtures: 80/20; 50/50; 20/80; 0/100. 9 fractions numbered F1 to F9 were obtained. Fractions F1 to F5 were purified on HPLC with a linear gradient of hexane/isopropanol, by the following method: 70:30 changing over 2 min to $60: 40$, then to $40: 60$ at 10 min and pure isopropanol at $15 \mathrm{~min}$ and remaining as is for $5 \mathrm{~min}$. The fractions F6 and F9 were analyzed and purified with an isocratic method: 30:70 hexane/isopropanol. These methods allowed us to isolate moracin M 1 (6.2 mg; w/w 0.019\%), moracin N 2 (6.7 mg; w/w 0.020\%), 6-O- 
methyl-moracin M 3 (3.3 mg; w/w 0.010\%), 6-O-methyl-moracin-N 4 (9.1 mg; w/w 0.027\%), moracin Z 5 (5.2 mg; w/w 0.016\%), moracin P 6 (1.2 mg; w/w 0.003), trans-resveratrol 7 (12.6 mg; w/w 0.038\%), trans-oxyresveratrol 8 (112.3 mg; w/w 0.343\%), arachidin 29 (5.1 mg; w/w 0.015\%), arachidin $4 \mathbf{1 0}(0.4 \mathrm{mg} ;$ w/w $0.001 \%)$, alboctalol $11(0.5 \mathrm{mg}$; w/w 0.001\%), (-)-epialboctalol 12 (5.4 mg; w/w 0.016\%), artogomezianol 13 (12.7 mg; w/w 0.038\%), steppogenin 14 (11.5 mg; w/w 0.035\%), katuranin 15 (1.5 mg; w/w 0.004\%), dihydromorin 16 (20.4 mg; w/w 0.062\%), the $\beta$-sitosterol 17 (8.4 mg; w/w 0.025\%) and the resorcinol 18 (1.8 mg; w/w 0.005\%). Compounds 1-6, 9-10 and 17-18 were obtained from the purification of the fractions F1-F5 while compounds 7-8 and 11-16 were isolated from the fractions F6-F9.

\subsubsection{6-O-Methyl-moracin M (3)}

Yellowish amorphous powder; HR-EIMS $[\mathrm{M}+\mathrm{H}]^{+} \mathrm{m} / z$ 257.0805 $[\mathrm{M}+\mathrm{H}]^{+}(\operatorname{calcd} 257.0808)$; ${ }^{1} \mathrm{H}$ and ${ }^{13} \mathrm{C}$ NMR $\left(500 \mathrm{MHz} ; \mathrm{CD}_{3} \mathrm{OD}\right)$ see table 1.

\subsubsection{6-O-Methyl-moracin N (4)}

Yellowish amorphous powder; HR-EIMS $[\mathrm{M}+\mathrm{H}]^{+} \mathrm{m} / z$ 325.1437 $[\mathrm{M}+\mathrm{H}]^{+}(\operatorname{calcd} 325.1434)$;

${ }^{1} \mathrm{H}$ and ${ }^{13} \mathrm{C}$ NMR $\left(500 \mathrm{MHz} ; \mathrm{CD}_{3} \mathrm{OD}\right)$ see table 1.

\subsubsection{Moracin Z (5)}

Yellowish amorphous powder; HR-EIMS $[\mathrm{M}+\mathrm{H}]^{+} \mathrm{m} / z 343.1542[\mathrm{M}+\mathrm{H}]^{+}($calcd 343.1540);

${ }^{1} \mathrm{H}$ and ${ }^{13} \mathrm{C}$ NMR (500 MHz; $\left.\mathrm{CD}_{3} \mathrm{OD}\right)$ see table 1.

$$
\text { 4.3.4 Arachidin } 4(\mathbf{1 0})
$$

Colorless syrup; HR-EIMS $[\mathrm{M}+\mathrm{H}]^{+} \mathrm{m} / z, 315.1592[\mathrm{M}+\mathrm{H}]^{+}($calcd 315.1591$) ;{ }^{1} \mathrm{H}$ and ${ }^{13} \mathrm{C}$ NMR (500 MHz; $\left.\mathrm{CD}_{3} \mathrm{OD}\right)$ see table 2.

\subsection{5 (-)-Epialboctalol (12)}

Brownish syrup; $[\alpha]_{\mathrm{D}}{ }^{20}-7.4^{\circ}\left(\mathrm{c} 0.004, \mathrm{CH}_{3} \mathrm{OH}\right) ;$ HR-EIMS $[\mathrm{M}+\mathrm{H}]^{+} \mathrm{m} / z$ 489.1540 $[\mathrm{M}+\mathrm{H}]^{+}$ (calcd 489.1544); ${ }^{1} \mathrm{H}$ and ${ }^{13} \mathrm{C}$ NMR (500 MHz; $\left.\mathrm{CD}_{3} \mathrm{OD}\right)$ see table 3. 
The 3 known moracins M (1), N (2) and P (6) and the other known compounds 7-9, 11, and

315 13-18 were identified by comparison of their physical and spectral data with those reported in 316 the literature.

\section{Role of the funding source}

The authors gratefully acknowledge the Programme Amazonie du CNRS for financial support, as well as the CNRS and the Région Guyane, France, for the research fellowship attributed to MR.

\section{References}

Aldrich Library of 13C and 1H FT NMR Spectra, 1992, 2, 207A; 243A (nmr).

Basnet P., Kadota S., Terashima S., Shimizu M., Namba T., 1993. Two new 2-arylbenzofuran derivatives from hypoglycemic activity-bearing fractions of Morus insignis. Chemical and Pharmaceutical Bulletin 41, 1238-1243.

Bates R.B., Caldera S., Deshpande V.H., Malik B.L., Paknikar S.K., 1997. Revised structure of alboctalol. Journal of Natural Products 60, 1041-1042.

Binbuga N., Ruhs C., Hasty J.K., Henry W.P., Schultz T.P., 2008. Developing environmentally benign and effective organic wood preservatives by understanding the biocidal and non-biocidal properties of extractives in naturally durable heartwood. Holzforschung 62, 264-269.

Chapman E., Hall W., 2006. Dictionary of Natural Products , CRC, Version 14:2.

Dani C., Bonnato D., Salvador M., Pereira M.D., Henriques J.A.P., Eleutherio E., 2008. Antioxidant protection of resveratrol and catechin in Saccharomyces cerevisiae. Journal of Agricultural and Food Chemistry 56, 4268-4272. 
Dat N.T., Jin X., Lee K., Hong Y.-S., Kim Y.H., Lee J.J., 2009. Hypoxia-Inducible Factor-1 Inhibitory Benzofurans and Chalcone-Derived Diels-Alder Adducts from Morus Species. Journal of Natural Products 72, 39-43.

Datwyler S.L., Weiblen G.D., 2004. On the origin of the fig: phylogenetic relationships of Moraceae from ndhF sequence. American Journal of Botany 91, 767-777.

El-Sohly H.N., Joshi A., Li X-C., Ross S.A., 1999. Flavonoids from Maclura tinctoria. Phytochemistry 52, 141-145.

Ferlinahayati S.Y.M., Juliawaty L.D., Achmad S.A., Hakim E.H., Takayama H., Said I.M., Latip J., 2008. Phenolic constituents from the wood of Morus australis with cytotoxic activity. Zeitschrift fur Naturforschung - Section C. Journal of Biosciences 63, 35-39.

Ferrari F., Cechinel Filho V., Cabras T., Messana I., 2003. Sorocein L and sorocein M: two Diels-Alder type adducts from Sorocea ilicifolia. Journal of Natural Products 66, 581582.

Han A-R., Kang Y-J., Windono T., Lee S.K., Seo E-K., 2006. Prenylated flavonoids from heartwood of Artocarpus communis with inhibitory activity on lipopolysaccharideinduced nitric oxide production. Journal of Natural Products 69, 719-721.

Hart J.H., Shrimpton D.M., 1979. Role of stilbenes in resistance of wood to decay. Phytopathology 69, 1138-1143.

Hirakura K., Fujimoto Y., Fukai T., Nomura T., 1986. Two phenolic glycosides from the root bark of the cultivated mulberry tree (Morus lhou). Journal of Natural Products 49, 218-224

Hsu, F.-L., Chang H.-T., Chang S.T., 2007. Evaluation of antifungal properties of octyl gallate and its synergy with cinnamaldehyde. Bioresource Technology 98, 734-738. 
Iacopini P., Baldi M., Storchi P., Sebastiani L., 2008. Catechin, epicatechin, quercetin, rutin and resveratrol in red grape: content, in vitro antioxidant activity and interactions. Journal of Food Composition and Analysis 21, 589-598.

Jahasinghe U.L.B., Samarakoon T.B., Kumarihamy B.M.M., Hara N., Fujimoto Y., 2008. Four new prenylated flavonoids and xanthones from the root bark of Artocarpus nobilis. Fitoterapia 79, 37-41.

Jayasinghe U.L.B., Puvanendran S., Hara N., Fujimoto Y., 2004. Stilbene derivatives with antifungal and radical scavenging properties from the stem bark of Artocarpus nobilis. Natural Products Research 18, 571-574.

Lee D., Bhat K.P.L., Fong H.H.S., Farnsworth N.R., Pezzuto J.M., Kinghorn A.D., 2001. Aromatase Inhibitors from Broussonetia papyrifera. Journal of Natural Products 64, $1286-1293$.

Lee Y.J., Kim S., Lee S.J., Ham I., Whang W.K., 2009. Antioxydant activities of new flavonoids from Cudrania tricuspidata root bark. Archives of Pharmacal Research 32, 195-200.

Li H., Cheng K.W., Cho C.H., He Z., Wang M., 2007. Oxyresveratrol as an antibrowning agent for cloudy apple juices and fresh-cut apples. Journal of Agricultural and Food Chemistry 55, 2604-2610.

Likhitwitayawuid K., Sritularak B., 2001. A new dimeric stilbene with tyrosinase inhibitiory activity from Artocarpus gomezianus. Journal of Natural Products 64, 1457-1459.

Luo M., Liang X.Q., Dang P., Holbrook C.C., Bausher M.G., Lee R.D., Guo B.Z., 2005. Microarray-based screening of differentially expressed genes in peanut in response to Aspergillus parasiticus infection and drought stress. Plant Science 169, 695-703.

Mabberley D.J. (2002) The Plant Book, second Ed, Cambride University Press, 858 p. 
Murti V.V.S., Seshadri T.R., Sivakumaran S., 1972. Cudriniaxanthon and butyrospermol acetate from the roots of Cudrania javanensis. Phytochemistry 11, 2089-2092.

Ngadjui B.T., Watchueng J., Keumedjio F., Nagmeni B., Simo I.K., Abegaz B.M., 2005. Prenylated chalcones, flavones and other constituents of the twigs of Dorsteronia angusticornis and Dorsteronia barteri var. subtriangularis. Phytochemistry 66, 687692.

Nguyen T.D., Jin X., Lee K., Hog Y-S., Young H.K., Jung J.L., 2009. Hypoxia-inducible factor-1 inhibitory benzofurans and chalcone-derived Diels-Alder adducts from Morus species. Journal of Natural Products 72, 39-43.

Okitani T., Takabe K., Takahashi M., 1999. The role of extractives involved in the natural durability of domestic softwood. Wood Research 86, 51-52.

Orsini F., Verotta L., Lecchi M., Restano R., Curia G., Redaelli E., Wanke E., 2004. Resveratrol derivatives and their role as potassium channels modulators. Journal of Natural Products 67, 412-426.

Ross S.A., Rodríguez-Guzmán R., Radwan M.M., Jacob M., Ding Y., Li X.-C., Ferreira D., Manly S.P., 2008. Sorocenols G and H, anti-MRSA oxygen heterocyclic Diels-Aldertype adducts from Sorocea muriculata roots. Journal of Natural Products 71, 17641767.

Rowe J.W., Conner A.H., 1979. Extractives in Eastern Hardwood. A review. USDA Forest Service General Technical Report FPL 18. Forest Products Laboratory, Madison, WI, $66 \mathrm{pp}$.

Scheffer T.C., Morell J.J., 1998. Natural durability of wood: A worldwide checklist of species. Forest Research Laboratory, Oregon State university; College of Forestry, Research Contribution 22, 45 pp. 
Schultz P., Hubbard J.T.F., Jin L., Fisher T.H., Nicholas D.D., 1990. Role of stilbenes in the natural durability of wood: Fungicidal structure-activity relationships. Phytochemistry 29, 1501-1507.

Schultz T.P., Harms W.B., Fischer T.H., McMurtrey K.D., Minn J., Nicholas D.D., 1995. Durabiliy of angiosperm heartwood: the importance of extractives. Holzforschung 49, 29-34.

Schultz P., Nicholas D., 2000. Naturally durable heartwood: evidence for a proposed dual defensive function of the extractives. Phytochemistry 5, 47-52.

Schultz P., Nicholas D., Preston A.F., 2007. A brief review of the past, present and future of wood preservation. Pest Management Science 63, 784-788.

Sheu Y-W., Chiang L-C., Chen I-C., Tsai I-L., 2005. Cytotoxic flavonoids and new chromenes from Ficus formosana f. formosana. Planta Medica 71, 1165-1167.

Shimizu K., Kondo R., Sakai K., Lee S-H., Sato H., 1998. The inhibitory component from Artocarpus incisus on melanin biosynthesis. Planta Medica 64, 408-412.

Silva C.A., Monteiro B.B., Brazolin S., Lopez A.C.G., Richter A., Braga M.R., 2007. Biodeterioration of brazilwood Caesalpinia echinata Lam. (LeguminosaeCaesalpinioideae) by rot fungi and termites. International Biodeterioration and Biodegradation 60, 285-292.

Smith A.L., Campbell C.L., Diwakar M.P., Hanover J.W., Miller R.O., 1989. Extracts from black locust as wood preservatives: A comparison of the methanol extract with pentachlorophenol and chromated copper arsenate. Holzforschung 43, 293-296.

Song W., Wang H-H., Bucheli P., Zhang P-F., Wei D-Z., Lu Y-H., 2009. Phytochemical profiles of different mulberry (Morus sp.) species from China. Journal of Agricultural and Food Chemistry 57, 9133-9140. 
Su B.N., Cuendet M., Hawthorne M.E., Kardono L.B.S., Riswan S.F., Harry H.S., Mehta R.G., Pezzuto J.M., Kinghorn A.D., 2002. Constituents of the bark and twigs of Artocarpus dadah with cyclooxygenase inhibitory activity. Journal of Natural Products 65, 163-169.

Suttie E.D., Orsler R.J., 1996. The influence of the natural extractives of Opepe (Nauclea diderrichii) and African Padauk (Pterocarpus soyauxii) timbers on their durability. IRG/WP N 96-30098, 1-15.

Takasugi M., Nagao S., Masamune T., 1979. Structure of moracins E, F, G and H, new phytoalexins from diseased mulberry. Tetrahedron Letters 48, 4675-4678.

Wang S.Y., Chen P.F., Chang S.T., 2005. Antifungal activities of essential oils and their constituents from indigenous cinnamon (Cinnamomum osmophloeum) leaves against wood decay fungi. Bioresource Technology 96, 813-818.

Zerega N.J.C., Clement W.L., Datwyler S.L., Weiblen G.D., 2005. Biogeography and divergence times in the mulberry family (Moraceae). Molecular Phylogenetics and Evolution 37, 402-416.

Zhou C.X., Tanaka J., Cheng C.H.K., Higa T., Tan R.X., 1999. Steroidal alkaloids and stilbenoids from Veratrum taliense. Planta Medica 65, 480-482. 


\section{$452 \quad$ Figures and legends}

Moracins

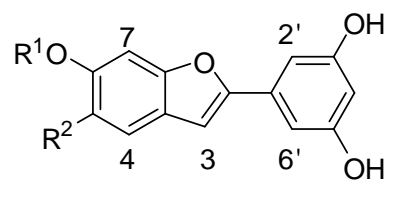

Moracin M

Moracin N

6-O-Methyl-moracin $\mathrm{M}$

6-O-Methyl-moracin $\mathrm{N}$

Moracin $Z^{b}$

Stilbenoids<smiles>[R2]c1cc(O)ccc1/C=C/c1ccc(O)c(O)c1</smiles>

$\mathrm{R}^{1} \mathrm{R}^{2}$

$7 \mathrm{H} \quad \mathrm{H}$

$8 \mathrm{OH} \mathrm{H}$

$1 \mathrm{H} \quad \mathrm{H}$

$2 \mathrm{H}$ Prenyl

$3^{\mathrm{a}} \mathrm{Me} \mathrm{H}$

$4^{\text {a }}$ Me Prenyl

$5^{\mathrm{a}} \mathrm{Me}$ 3-Hydroxy-3-methylbutyl

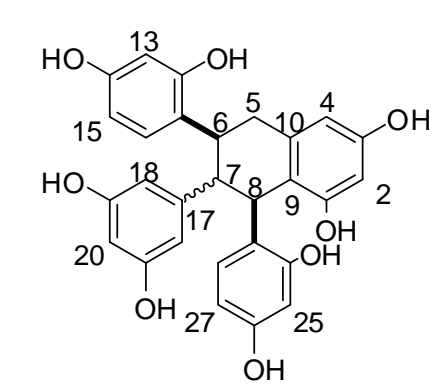

$$
\begin{array}{lll}
11 & C_{17}-C_{7} & \text { Alboctalol } \\
1^{\mathrm{a}} \mathrm{C}_{17}{ }^{\prime \prime} \mathrm{C}_{7} & (-) \text {-Epialboctalol }
\end{array}
$$<smiles>Oc1cc(O)cc(/C=C/c2cc(C(Cc3cc(O)cc(O)c3)c3ccc(O)cc3O)c(O)cc2O)c1</smiles>

13 Artogomezianol

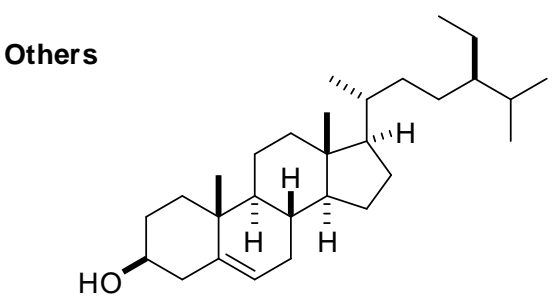<smiles>Oc1cccc(O)c1</smiles>

$17 \beta$-Sitosterol

18 Resorcinol

454 Figure 1 Compounds 1-18 isolated from Bagassa guianensis (Moraceae). (a) New 


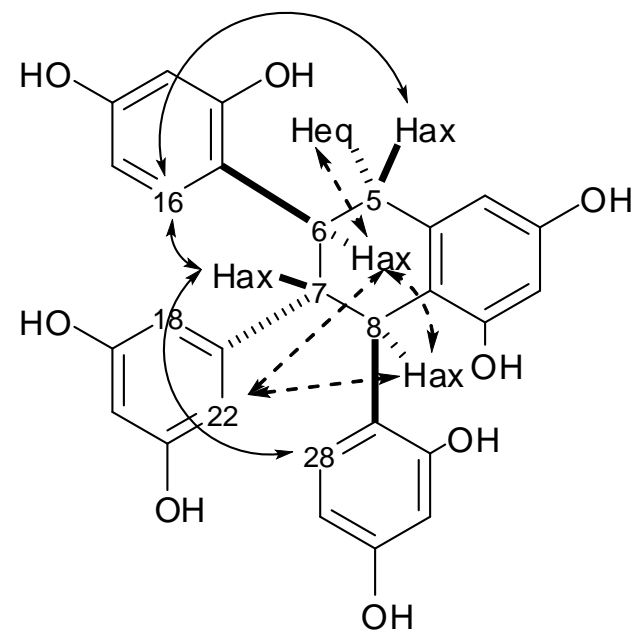

458

459 Figure 2 Pertinent NOE interactions observed for (-)-epialboctalol (12) from NOESY 460 experiment

461 
463 Tables

464 Table $1{ }^{1} \mathrm{H}$ and ${ }^{13} \mathrm{C}$ NMR spectroscopic data for moracins 3-5 in $\mathrm{CD}_{3} \mathrm{OD}$

\begin{tabular}{|c|c|c|c|c|c|c|}
\hline \multirow{2}{*}{ Atom } & \multicolumn{2}{|l|}{3} & \multicolumn{2}{|l|}{4} & \multicolumn{2}{|l|}{5} \\
\hline & $\delta_{\mathrm{C}}$ & $\delta_{\mathrm{H}}(J$ in $\mathrm{Hz})$ & $\overline{\delta_{\mathrm{C}}}$ & $\delta_{\mathrm{H}}(J$ in $\mathrm{Hz})$ & $\delta_{\mathrm{C}}$ & $\delta_{\mathrm{H}}(J$ in $\mathrm{Hz})$ \\
\hline 2 & 156.5 & - & 156.2 & - & 156.2 & - \\
\hline 3 & 96.5 & $6.95, \mathrm{~d}(0.6)$ & 102.1 & $6.90, \mathrm{~s}$ & 102.0 & $6.91, \mathrm{~d}(0.6)$ \\
\hline 4 & 121.9 & $7.43, \mathrm{~d}(8.5)$ & 121.3 & $7.25, \mathrm{~s}$ & 121.6 & $7.30, \mathrm{~s}$ \\
\hline 5 & 112.9 & $6.85, \mathrm{dd}(8.5,2.1)$ & 127.5 & - & 128.6 & - \\
\hline 6 & 159.6 & - & 157.4 & - & 157.5 & - \\
\hline 7 & 102.0 & 7.09, brd (2.0) & 94.7 & 7.09, s & 94.7 & 7.09, s \\
\hline 8 & 157.0 & - & 155.7 & - & 155.8 & - \\
\hline 9 & 123.7 & - & 123.0 & - & 123.1 & - \\
\hline 1 ' & 133.6 & - & 133.9 & - & 133.6 & - \\
\hline $2 \% / 6 ’$ & 104.0 & $6.78, \mathrm{~d}(2.1)$ & 103.9 & $6.77, \mathrm{~d}(2.1)$ & 103.5 & $6.77, \mathrm{~d}(2.1)$ \\
\hline $3 ' / 5$ & 159.7 & - & 159.9 & - & 160.0 & - \\
\hline $4^{\prime}$ & 103.5 & $6.25, \mathrm{t}(2.1)$ & 103.5 & $6.24, \mathrm{t}(2.1)$ & 103.4 & $6.25, \mathrm{t}(2.1)$ \\
\hline 1, & - & - & 29.7 & 3.34, brd (7.3) & 26.7 & $2.73, \mathrm{~m}$ \\
\hline $2 \%$ & - & - & 124.3 & $5.32, \operatorname{tm}(7.3)$ & 45.5 & $1.74, \mathrm{~m}$ \\
\hline $3 "$ & - & - & 132.7 & - & 71.5 & - \\
\hline $4 "$ & - & - & 17.8 & $1.73 \mathrm{brs}$ & 28.9 & $1.27, \mathrm{~s}$ \\
\hline 5, & - & - & 26.0 & 1.74 brs & 28.9 & $1.27, \mathrm{~s}$ \\
\hline $\mathrm{MeO}$ & 56.0 & $3.85, \mathrm{~s}$ & 56.2 & $3.88 \mathrm{~s}$ & 56.0 & $3.89, \mathrm{~s}$ \\
\hline
\end{tabular}


467 Table $2{ }^{1} \mathrm{H}$ and ${ }^{13} \mathrm{C}$ NMR spectroscopic data for stilbenes 9 and $\mathbf{1 0}$ in $\mathrm{CD}_{3} \mathrm{OD}$

\begin{tabular}{|c|c|c|c|}
\hline \multirow{2}{*}{ Atom } & \multicolumn{2}{|l|}{9} & \multirow{2}{*}{$\begin{array}{l}\mathbf{1 0} \\
\delta_{\mathrm{H}}(J \text { in } \mathrm{Hz})\end{array}$} \\
\hline & $\delta_{\mathrm{C}}$ & $\delta_{\mathrm{H}}(J$ in $\mathrm{Hz})$ & \\
\hline 1 & 130.6 & - & - \\
\hline 2 & 128.6 & $7.31, \mathrm{~d}(8.6)$ & $7.32, \mathrm{~d}(8.7)$ \\
\hline 3 & 116.5 & $6.75, \mathrm{~d}(8.6)$ & $6.75, \mathrm{~d}(8.7)$ \\
\hline 4 & 158.1 & - & - \\
\hline 5 & 116.5 & $6.75, \mathrm{~d}(8.6)$ & $6.75, \mathrm{~d}(8.7)$ \\
\hline 6 & 128.6 & $7.31, \mathrm{~d}(8.6)$ & $7.32, \mathrm{~d}(8.7)$ \\
\hline$\alpha$ & 128.3 & $6.88, \mathrm{~d}(16.3)$ & $6.90, \mathrm{~d}(16.5)$ \\
\hline$\beta$ & 127.2 & $6.74, \mathrm{~d}(16.3)$ & $6.74, \mathrm{~d}(16.5)$ \\
\hline 1 , & 137.6 & - & - \\
\hline $2^{\prime}$ & 105.7 & $6.46, \mathrm{~s}$ & $6.46, \mathrm{~s}$ \\
\hline $3^{\prime}$ & 157.2 & - & - \\
\hline $4^{\prime}$ & 116.0 & - & - \\
\hline $5^{\prime}$ & 157.2 & - & - \\
\hline $6^{\prime}$ & 105.7 & $6.46, \mathrm{~s}$ & $6.46, \mathrm{~s}$ \\
\hline $1 '$, & 23.3 & $3.28, \mathrm{~d}(7.1)$ & $2.66, \mathrm{~m}$ \\
\hline $2^{\prime \prime}$ & 124.6 & $5.23, \mathrm{tm}(7.1)$ & $1.68, \mathrm{~m}$ \\
\hline 3, & 131.4 & - & - \\
\hline 4, & 26.0 & $1.62, \mathrm{brs}$ & $1.25, \mathrm{~s}$ \\
\hline 5, & 18.0 & 1.75, brs & $1.25, \mathrm{~s}$ \\
\hline
\end{tabular}

468

469 
471 Table $3{ }^{1} \mathrm{H}$ and ${ }^{13} \mathrm{C}$ NMR spectroscopic data for distilbenes $\mathbf{1 1}$ and $\mathbf{1 2}$ in $\mathrm{CD}_{3} \mathrm{OD}$

\begin{tabular}{|c|c|c|c|}
\hline \multirow{2}{*}{ Atom } & \multicolumn{2}{|l|}{12} & \multirow{2}{*}{$\begin{array}{l}11 \\
\delta_{\mathrm{H}}(J \text { in } \mathrm{Hz})\end{array}$} \\
\hline & $\delta_{\mathrm{C}}$ & $\delta_{\mathrm{H}}(J$ in $\mathrm{Hz})$ & \\
\hline 1 & 156.7 & - & - \\
\hline 2 & 101.8 & $6.10, \mathrm{~d}(2.2)$ & $6.32, \mathrm{~d}(2.2)$ \\
\hline 3 & 156.2 & - & - \\
\hline 4 & 107.3 & $6.19, \mathrm{~d}(2.2)$ & $6.32, \mathrm{~d}(2.2)$ \\
\hline $5_{\mathrm{ax}}$ & 40.1 & 3.19 , brt (13.7) & $2.98, \mathrm{dd}(16,14)$ \\
\hline $5_{\text {eq }}$ & & $2.72, \mathrm{dd}(15.6,3.0)$ & $2.53, \mathrm{dd}(16.3,4.3)$ \\
\hline $6 \mathrm{ax}$ & 40.3 & 3.51, brtd $(11.6,2.1)$ & $3.75, \mathrm{dt}(14,3.7)$ \\
\hline $7_{\mathrm{ax}}$ & 56.2 & 3.41 , dd $(11.3,8.2)$ & - \\
\hline $7_{\text {eq }}$ & - & - & $3.28, \mathrm{~d}(3.3)$ \\
\hline 8 ax & 44.1 & $4.42, \mathrm{~d}(8.2)$ & 4.67, brs \\
\hline 9 & 119.6 & - & - \\
\hline 10 & 142.2 & - & - \\
\hline 11 & 123.7 & - & - \\
\hline 12 & 156.4 & - & - \\
\hline 13 & 103.3 & $6.16, \mathrm{~d}(2.2)$ & $?$ \\
\hline 14 & 156.4 & $6.12, \mathrm{dd}(8.4,2.3)$ & $6.13, \mathrm{dd}(8.4,2.3)$ \\
\hline 15 & 107.3 & - & - \\
\hline 16 & 129.7 & $6.82, \mathrm{~d}(8.2)$ & $6.44, \mathrm{~d}(8.2)$ \\
\hline 17 & 149.2 & - & - \\
\hline 18 & 108.4 & $6.01, \mathrm{~d}(1.9)$ & $5.77, \mathrm{~d}(1.9)$ \\
\hline 19 & 157.9 & - & - \\
\hline 20 & 100.8 & $5.93, \mathrm{t}(2.2)$ & $6.02, \mathrm{t}(2.2)$ \\
\hline 21 & 157.9 & - & - \\
\hline 22 & 108.4 & $6.01, \mathrm{~d}(1.9)$ & $5.77, \mathrm{~d}(1.9)$ \\
\hline 23 & 125.2 & - & - \\
\hline 24 & 156.1 & $6.76, \mathrm{~d}(8.2)$ & $6.25, \mathrm{~d}(8.2)$ \\
\hline 25 & 103.2 & $6.23, \mathrm{dd}(8.2,2.5)$ & $6.04, \mathrm{dd}(8.2,2.5)$ \\
\hline 26 & 156.7 & - & - \\
\hline 27 & 108.1 & $6.19, \mathrm{~d}(2.2)$ & $6.25, \mathrm{~d}(2.2)$ \\
\hline 28 & 131.2 & - & - \\
\hline
\end{tabular}

